\title{
EMPLOYEE ASSISTANCE PROGRAMMES: THEIR RATIONALE, BASIC PRINCIPLES AND ESSENTIAL ELEMENTS
}

\section{Lobelo Mogorosi}

\section{INTRODUCTION}

This paper presents background information about workplace programmes that provide needed personal and social services to employees. These programmes are commonly referred to as Employee Assistance Programmes (EAPs). The paper deals with the theoretical background to aid an understanding of what these programmes are about. The discussions revolve around three aspects: reasons why organisations establish these programmes; their underlying principles and their essential elements; and the programme services, functions and structure. In the first section, which focuses on the reasons for programme establishment, a short list is provided of the commonly given reasons why organisations establish such programmes to assist their employees. The second section focuses on programmes' basic principles, while the third discusses twelve essential elements of these programmes. The paper ends with a descriptive illustration of programme development within a higher education institution in which the author participated. This takes the form of tabular presentations of programme functions and services as well as its structure. As the paper is directed at the social work fraternity, it is important to begin by defining and explaining the relationship between workplace programmes and social work, through the route of elucidating occupational social work.

\section{SOCIAL WORK AND EMPLOYEE ASSISTANCE PROGRAMMES}

The article "Breaking Down Barriers" (2006:1) explains the general purpose of social work as a discipline well, stating that "at the heart of social work is the desire to help people in need, whether it is fighting AIDS, overcoming poverty, or pursing justice in a court of law". As a profession social work is about improvement of social functioning for individuals, groups and communities. It is a practice-oriented profession grounded in the core values of self-determination, empowerment, as well as in the belief of the inherent worth and dignity of all human beings (Pincus \& Minaham, 1973; Zastrow, 1993). Social work at the workplace is one of the specialised fields within the discipline. The term that is commonly used for this area of the discipline is occupational social work. Social workers in this situation provide services to employees attached to a work organisation. Depending on the mandate, resources and service scope, programme services may be extended to employees' family members and significant others.

\section{Occupational social work/social work at the workplace}

Akabas and Kurzman (1982:197) describe occupational social work as a special field of practice where the focus is the individual worker. Kurzman (1987:899) defines occupational social work as those programmes and services "under the auspices of labour or management, that utilise professional social workers to serve members or employees and the legitimate social welfare needs of the labour or industrial organisation”. Kurzman (1992) adds that to provide specific social services under a contractual agreement, professionally trained social workers or institutions such as voluntary or social agencies can be called upon to provide the needed services to members of trade unions or employees of work organisations. 
Smith and Gould (1993:12) describe employee assistance or counselling as the "best-known model of social work practice at the workplace". They observe that this model can also be used for proactive advocacy for other programmes, such as health promotion and disease-prevention programmes at the workplace. They further note that "this form of occupational social work is characterised by policies, procedures and counselling-oriented services to identify or respond to employees with personal, emotional, or behavioural problems, especially those that interfere with their performance at work".

Common elements within the definitions used for occupational social work, include the following aspects (Akabas \& Kurzman, 1982; Kurzman, 1992; Smith \& Gould, 1993; Straussner, 1990):

- The use of some social work method and skills (e.g. casework and counselling);

- Model of workplace programme practice (e.g. employee assistance programme); and

- The focus of service being on employees with social welfare needs, and the question of auspices of service (labour, management or joint).

For what occupational social workers do, Akabas (1995) provides a list of tasks that they are expected to perform in their professional capacities within work-based programmes. These tasks include:

- consultations around individual employee needs and policy situations;

- client assessment and intervention, using short-term and crisis intervention methodologies;

- facilitation of negotiations and resolution of conflicts between employees and their supervisors and managers; and

- advocacy on behalf of clients, and referrals to and the development of relationships with community-based service providing agencies.

\section{Employee Assistance Programmes (EAPs)}

Taylor, Holosko, Wayne-Smith and Feit (1988) define employee assistance programmes as employment-based services whose purpose is to assist individuals experiencing personal problems, by both assessing the nature of their difficulties and making referrals to appropriate helping resources. These programmes operate within the context of work environments and are subsequently influenced by their positions within the organisational structure. For Du Plessis (1991:20) these programmes are aimed at linking employees with personal problems to appropriate resources in order to correct or prevent a deterioration in job performance. Sonnenstuhl and Trice (1990:1) see these programmes as job-based programmes operating within organisations "for the purpose of identifying troubled employees, motivating them to resolve their troubles, and providing access to counselling or treatment for those who need the services". In addition, the definition of EAP by the Employee Assistance Programme Association - South Africa (EAPA-SA) focuses on the issue that such programmes revolve around the identification and resolution of "productivity problems associated with employees impaired by personal concerns" (EAPA-SA, 2005:5).

Sonnenstuhl and Trice (1990:1) refer to the "troubled employee" as the focus of such services. They allude to the fact that the services provided are workplace-based and are for "troubled employees" as well as for employees who are experiencing personal problems leading to a deteriorating job performance (Blum \& Roman, 1988; Blum, 2004; Daniels, 1997; Du Plessis, 1992; Mogorosi, 1997; Myers, 1984; Sonnenstuhl \& Trice, 1990; Taylor et al., 1988). De Winnaar and Taute (2008:263) add the factor that such programmes assist with the process of "re-instatement of employees at the workplace". 
In this paper occupational social work (or social work at the workplace) is defined as a form of social work professional practice at the workplace, which uses a workplace programme as a model. Employee assistance programmes refer to support services set up with the aim of helping employees deal with individual or collective problems of a personal, familial or work nature. These programmes are work-based services funded and operated by an employing organisation, employees' unions or both. Some of these programmes are external and contracted by either one or both of the parties (i.e. employers or unions).

\section{RATIONALE FOR EMPLOYEE ASSISTANCE PROGRAMMES}

There are probably as many reasons to establish a programme as there are work organisations wishing to establish some kind of workplace-based services for their employees. The reasons for programme establishment range from one end of the benevolence spectrum to the other. There are those with positive or negative motives and those who have no knowledge of the subject, even though they may have the programmes. Usually the majority of work organisations establish programmes for practical reasons, including the expectation that such programmes will produce the intended results, whatever that may be. As the United States' Bureau of National Affairs Report - known as the BNA Report (1987:23) - aptly puts it in its discussion on the costs and benefits of such programmes, generally "employers do not establish EAPs for altruistic reasons. They want to know quantitatively that the money they spend on EAPs yield some tangible benefits to their firms in terms of reduced costs".

Reduced costs here, for example, refer to the often repeated justification that a programme helps an organisation to reduce employee problems and hence increase their productivity (Balgopal, 1989). As an example, historically unions in North America (the United States and Canada) viewed these programmes management tools to engender or gain employee loyalty, and therefore in the process undercut the influence of unions. The very same unions, however, are faced with the reality that their members need the help that is offered by these programmes (BNA Report, 1987). In the South African context, the unions' views on the programmes are still to be tested. In advocating for EAPs the agendas of both employers and unions are entirely different: "Workplace programmes are usually viewed differently by interested principal parties (management and employees/unions), in relation to the reasons and functions they are set to perform" (BNA Report, 1987:59). Employers establish programmes principally as a way to increase productivity and ensure a safer workplace. Unions, on the other hand, tend to view the EAP as a tool for helping workers keep their jobs.

A summary of the numerous reasons as to why EAPs are initiated includes the factors listed in Table 1. These reasons are discussed by various authors and researchers such as Akabas and Kurzman (1982), Myers (1984), BNA Report (1987), Balgopal and Patchner (1988), Smith (1988), Balgopal (1989), Roman (1990), Sonnenstuhl and Trice (1990), Du Plessis (1991), Kurzman (1993), Josias (2005) and Pace (2006). 


\section{TABLE 1}

RATIONALE FOR EMPLOYEE ASSISTANCE PROGRAMMES

- Contribute to efforts to humanise the workplace

- Meeting the needs of changing work environment

- Meeting the needs of changing workforce

- Helping to improve employee work performance

- Containing and reducing organisational costs, in relation to attending to employee challenges and problems, such as acclimatisation, absenteeism, discrimination and substance abuse

- Meeting employee health and general wellbeing needs

- Helping to maintain and increasing employee work commitment and loyalty

- Helping organisation with evaluation and feedback about reactions of employees on variety of issues

- Improving general management-employee relations

- Meeting legal and social responsibilities of organisations

Historically, significant recommendations were made to work organisation to ease union scepticism towards these programmes within the North American context. The American Federation of State, County and Municipal Employees Union (AFSCME), recommended the following important "precautions" to protect union members' rights in relation to the establishment of EAPs by organisations (BNA Report, 1987):

- Individual employees' voluntary programme participation and guaranteed confidentiality;

- Central, private and convenient location for the programme's offices;

- Organisational insurance coverage for programme-related services, and

- Programmes should not to be used to circumvent union-management agreements. For example, participation in the programme should have no bearing on agreements on grievance, disciplinary and promotion procedures.

\section{THREE BASIC PRINCIPLES OF EMPLOYEE ASSISTANCE PROGRAMMES}

This section focuses on three basic programme principles that help to clarify structures, roles and responsibilities. For their operational success EAPs should be based on a set of written policies and principles that would form the cornerstones of their effectiveness and also help clarify the roles of all those involved. Sonnenstuhl and Trice (1990) suggest that programme policies be guided by the following three basic principles (Blum, 2004; Sonnenstuhl \& Trice, 1992).

\section{Principle I ("EAP is a job-based strategy for helping employees to solve their problems")}

At some stage of their work life, it should be expected that employees, like everyone else, will experience some problems - either personal or related to work. The very recognition of this fact would go a long way in helping to establish harmonious relations between management and employees. When some of the employees' problems affect their work performance, an organisation has some obligation to offer help. People with problems have the right to resolve them the way they see fit. There are problems, however, that may have an effect on, or spill over to, work performance (e.g. absenteeism and addiction). At that point the organisation can 
offer help. Balgopal and Patchner (1988:95) state that "it is assumed that employees' problems are private unless they cause job performance to deteriorate. For when that happens, personal problems become a matter of concern for the company, as it is protecting its valuable asset - the trained employee."

\section{Principle II ("Constructive confrontation is used to motivate employees to resolve their problems and overcome denial")}

The important duty of managers or supervisors is to see to it that work is done appropriately. Whenever managers and supervisors observe the deterioration of work performance, it is their duty to help the employee correct that. Organisations need to have disciplinary and grievance procedures through which supervisors and managers can 'confront' employees about their poor work performance, should it continue. Employees may either acknowledge problems, deny their existence, or may be unaware of their performance problems. It would be during such a "constructive confrontation" process that supervisors and managers discuss poor work performance and how best to reverse the situation. This is done by suggesting that the employees concerned should seek help from the programme's services. Even though usage of programme services should never be used as a way to avoid disciplinary procedures, one of the possible outcomes of failure to deal with problems is disciplinary action that may be taken against employees because of their poor work performance. Constructive confrontation helps supervisors and managers to focus only on job performance, and refrain from making diagnosis of the problems by themselves. "Deteriorating work performance", which may precipitate constructive confrontation, is characterised by some of the following problems (Table 2) (Winkelpleck \& Smith, 1988).

TABLE 2

POINTERS FOR DETERIORATING EMPLOYEE WORK PERFORMANCE

- Increased absenteeism

- Unexpected vacation requests

- Sporadic and erratic work performance

- Tardiness and missed deadlines

- Increased strife with co-workers and supervisors

- Loss of enthusiasm for work

- Unpredictable behaviour patterns and moodiness

- Increased complaining

- Above average work accident rate and costly errors

- Difficulties with instructions

\section{Principle III ("Counselling is used to help employees solve their problems, when it} is clear that these problems are beyond the employees' control")

Sonnenstuhl and Trice's (1990) third principle states that EAPs policies need to reflect that employees will be helped to work through their problems, when both the employee and the organisation agree that some action would be necessary. Employees on their own, however, are expected to rely on their own solutions and resources so as to maintain their independence. When employee resources are exhausted and the problems are beyond their control, outside help may be called upon. These include the employing organisation. 


\section{ESSENTIAL ELEMENTS OF EMPLOYEE ASSISTANCE PROGRAMMES}

The twelve common elements characterising EAPs are discussed by most authors in the field, including Erfurt and Foote (1984), Myers (1984), Balgopal and Patchner (1988), Roman (1990), Sonnenstuhl and Trice (1990), Kurzman (1993) and Pace (2006). These elements contribute towards understanding what is needed in such programmes. What, then, are the crucial ingredients that help to ensure the success of employee assistance programmes?

\section{Management endorsement}

It is vital that organisational management endorses the programme and what it sets out to do. There is also a need for active involvement from the highest level of management or corporate structures of the organisation for the programme to succeed. Organisational leadership is always carefully watched to set the tone in terms of how any policy or programme is actively supported. Programme endorsement can be demonstrated by management's vocal and practical endorsements of activities being carried out by the programme. For example, managers may attend some of the scheduled employees' or supervisors' orientation, information and training sessions.

\section{Employee and union endorsement}

Not all organisation's endeavours are going to gain support of employees and their unions. Organised labour and staff need to participate in these programmes, as clients of these programmes are their members. Without union support the programmes may be viewed with suspicion, scepticism and resistance. To ensure support, proper consultation processes need to take place among all parties concerned at the workplace.

\section{Voluntary participation}

The programme services need to be provided in a climate free of any form of coercion, and where all service users are treated equally. Employees should also feel that they are not compelled to consult the programme, and that even though they may be using the services, they have a right to disengage when they want to.

\section{Confidentiality and privacy}

A programme is likely to be more effective only if employees trust that services are provided within appropriate professional boundaries of confidentiality and privacy. Emphasising the importance of these issues, Myers (1984:75) says that employees' fear of broken confidentiality may result in co-workers learning about their problems and management using the information to make unfair decisions. Sources of confidentiality protection are found in both legal statutes and social work's code of professional ethics. Both can help to provide guidelines on how and when to disclose confidential information.

\section{Professional staff}

For programme staff to be able to deliver appropriate and effective services, they need to be trained and knowledgeable in the appropriate fields and have access to resources in areas of employee concerns. These include aspects such as counselling, substance abuse, health, financial and legal advocacy services, and also in organisational development and social responsibility. Occupational social workers, occupational nurses and counsellors bring with them, from their respective professional training, appropriate skills necessary for the challenges in the programme. 


\section{Supervisors and union representatives training}

Referring to the "job-performance model" of supervisory training in the then popular occupational alcoholism programme during the early 1970s, Sonnenstuhl and Trice (1990:18) point to the contribution of that training that could be incorporated into general supervisor training in the programmes:

- Emphasis on management's programme support;

- Explanation of supervisors' role in programme implementation; and

- Demonstration of how programmes can be helpful to supervisors and managers in their job responsibilities.

Employee leadership training for union representatives and stewards may be done at least once a year, covering a wide range of issues such as substance abuse, family problems, intervention strategies and the referral process.

\section{Broad service component}

Workplace programmes need to be able to respond to a wide range of employee problems and needs. Services made available depend on whether the programme is internal or external, narrow or broad-brush (comprehensive), run by management, labour union or jointly run by organisations and labour. Narrowly focused programmes may only provide information and refer employees to outside community resources. In contrast, comprehensive programmes provide a wider range of services to employees, even though they may still refer to other outside community resources. Comprehensive programmes also include training for managers and supervisors.

TABLE 3

PROGRAMMES AND SERVICE DESCRIPTIONS

\begin{tabular}{|l|c|}
\hline \multicolumn{1}{|c|}{ Specific programme services } & \\
\hline Does your programme provide the following specific services? & Yes (\%) \\
\hline I. Employee personal services (N=98) & $100 \%$ \\
1. Counselling and referrals & 80 \\
2. Financial advice & 57 \\
3. Housing issues & 90 \\
4. Alcoholism (counselling and referrals) & \\
\hline II. Work-related issues (N=98) & $83 \%$ \\
1. Absenteeism problems & 41 \\
2. Workplace safety & 70 \\
3. Work relations & 62 \\
4. Employee terminations & \\
\hline III. Health-related services (N=96) & $76 \%$ \\
1. Information/promotion & 92 \\
2. HIV/AIDS Education & \\
\hline IV. Training and staff development (N=96) & $44 \%$ \\
1. Employee education/training & 79 \\
2. Supervisor training & 44 \\
3. Cross-cultural issues & \\
\hline
\end{tabular}


South African programmes tend to offer broad service components. Mogorosi's (1997) survey of programmes countrywide a decade ago showed the following service offer trends shown (Table 3).

Study data showed that South African programmes offered most of the traditional EAP services. The majority of responding programme heads in the Mogorosi (1997) study indicated that their programmes dealt with a wide variety of employee personal, health and work-related problems and challenges, as well as addressing training needs. Subsequent studies by Ramokolo (2004), Chabeli (2006) and Khorommbi (2007) confirmed this trend, when they established that EAPs deal with a wide variety of issues, including work relationship challenges, employee personal problems (including marital, substance abuse and legal challenges), financial management difficulties, staff morale and productivity challenges, stress management and HIV/AIDS. These programmes address such problems and challenges through counselling, referrals, campaigns and training.

\section{Financial aspects}

Programme policy needs to spell out clearly all related financial matters. This, however, depends on the organisation and context. Work organisations need to make decisions about how much financial and practical responsibilities they can assume for the health and wellbeing of the staff. In South Africa, for example, major employers (in both public and private sectors) would have some kind of medical and service benefit schemes for their employees. But usually no financial transactions are discussed or entered into between the organisation and employees for the kind of services that the EAPs provide. Organisations would perceive the costs of running such programmes as having no ascribable relationship to their individual employees, outside of the fact that the services are for all of them.

\section{Programme accessibility}

Employees need access to the programmes in both a convenient and confidential manner. Whether it is an organisational in-house or union programme, a decision needs to be taken about how best to locate the programme within a site, because of possible problems of access and confidentiality. As Erfurt and Foote (1984:31) put it, "private isolated locations tend to be inaccessible and hard to find".

\section{Programme marketing}

To be accessible and effective, programmes need to 'market' themselves constantly at all levels within organisations. Marketing is the promotion to the organisation, staff and other employees of existing programme services. Ramokolo (2004) states the following as goals of marketing of programmes:

- To increase employees' knowledge of the EAP and its services;

- To increase familiarity and comfort with EAP's operations and to enhance the acceptance and use of the programme service;

- To increase utilisation of the programme services;

- To enhance the integration of the EAP within the host or contract organisation and promote a feeling of ownership by all stakeholders (managers, other staff and employees); and

- To maintain the visibility of the EAP and its presence as vital contributor to organisation's productivity, efficiency, work life, and employees' wellbeing. 
Marketing of an EAP occurs through various employee education forms such as posters, new employee induction and orientation sessions, information and workshop sessions with supervisors, union representatives and employee associations. Information about available services can be given through other departments, such as human resources and health /medical divisions, which are in constant contact with employees.

\section{Policy statement and service principles}

An EAP needs a clear policy statement and service principles, which include intentions, programme procedures and available services. This clarifies the duties, rights, responsibilities and privileges of all involved (i.e. management, programme staff, employees and union). Additionally, to ensure proper understanding of what the programme is for and how it operates, these service principles should be prominently displayed and distributed within the targeted population of a work organisation (EAPA-SA, 1999). This can be done in the form of wall poster statements and pamphlets, and incorporated into staff orientation, induction and general information booklets. Most of these service principles overlap with those discussed in general as "essential elements of a programme".

\section{TABLE 4 \\ PROGRAMME SERVICE POLICY PRINCIPLES*}

- Equality: Programme services are for all employees (permanent and contracted) regardless of rank or position. All must be treated equally.

- Confidentiality and privacy: Professional confidentiality is respected and the programme will strive towards service provision within an atmosphere of privacy and trust.

- Dignity and respect: Programme service will be provided courteously, with dignity and respect.

- Promptness of the service: Within practical realities, interventions of the programme should be timely.

- Information disclosure and misuse: Information obtained within the confines of professional helping processes, such as in counselling, problem solving and dispute resolution, will not be used or disclosed, without the permission of the persons concerned.

- Accessibility of programme services: Accessibility of services will be ensured within the bounds of practicality.

- Voluntary participation: Programme services are provided on the basis of willing participation of employees. Situations of mandatory referral will also be treated within the same basis of willingness to accept programme services.

- Non-victimisation: Employees who participate in programme activities will not be victimised. Participation in the programme activities should not have a bearing on an employee's job security, promotion or future prospects.

- Instrument of punishment: Even though referrals and professional recommendations of the programme staff will be required by the employer, the use of programme services will not be used as disciplinary measure. Programme services are to be utilised in the spirit of efforts to remedy problematic situations. The programme is not/cannot be used as an instrument of punishment.

- Professional service: Programme services that are professional will be rendered by qualified personnel. The programme and professional staff will assume a posture of noninterference in employer-employee relations.

(* EAPA-SA, 1999) 


\section{Programme evaluation}

Programme evaluation is a significant component of EAPs. This evaluation follows different paths and formats, as it is informed by the reasons for the exercise of the assessment of a specific programme. The evaluation may range from simple tabulation of employees' programme participation, their solicitation of the services, utilisation of the services, satisfaction with the services rendered, and the demonstration of the degree of popularity of the services or programme components among employees. To evaluate these programmes, a number of authors identified lists of elements that need to be included in such efforts. Table 5 presents five examples of suggested lists of elements of such programme evaluation efforts.

TABLE 5

SUGGESTED ELEMENTS OF PROGRAMME EVALUATION

\begin{tabular}{|c|c|}
\hline Authors & Elements of EAP evaluation \\
\hline $\begin{array}{l}\text { "Measures of work } \\
\text { performance" } \\
\text { Erfurt and Foote (1984) }\end{array}$ & $\begin{array}{l}\text { - Employee rate of absenteeism } \\
\text { - Number of disciplinary actions received } \\
\text { - Number of employee grievances filed } \\
\text { - Number of on-the-job accidents } \\
\text { - Number of employee visits to the medical unit } \\
\text { - Amount of workers' compensation claims and } \\
\text { Amount of sickness and accident claims paid }\end{array}$ \\
\hline $\begin{array}{l}\text { "Elements of programme } \\
\text { evaluation" } \\
\text { Taylor et al. (1988) }\end{array}$ & $\begin{array}{l}\text { - Policies and procedures } \\
\text { - Training of frontline supervisors } \\
\text { - Programme services and } \\
\text { - Follow-up work }\end{array}$ \\
\hline $\begin{array}{l}\text { "Six major criteria" } \\
\text { Fleisher and Kaplan (1988) }\end{array}$ & $\begin{array}{l}\text { - } \text { Confidentiality } \\
\text { - Accidents } \\
\text { - Staff expertise and availability } \\
\text { - Flexibility } \\
\text { - Accountability and } \\
\text { - } \text { Cost-effectiveness } \\
\end{array}$ \\
\hline $\begin{array}{l}\text { "Elements of programme } \\
\text { evaluation" } \\
\text { Chandler (1989) }\end{array}$ & $\begin{array}{l}\text { - Health and attitude of employees } \\
\text { - Absenteeism and productivity } \\
\text { - Cost-effectiveness and } \\
\text { - Reduction in grievances }\end{array}$ \\
\hline $\begin{array}{l}\text { "Evaluation of an EAP" } \\
\text { Khorommbi (2007) }\end{array}$ & $\begin{array}{l}\text { - Programme utilisation } \\
\text { - Programme penetration } \\
\text { - } \text { Referral sources } \\
\text { - } \text { Programme adequacy of the programme } \\
\text { - } \text { Compliance assessment } \\
\text { - Programme efforts } \\
\text { - Programme effectiveness } \\
\text { - } \text { Client satisfaction }\end{array}$ \\
\hline
\end{tabular}


Erfurt and Foote's (1984) "measures of work performance" are based mostly on specific counts of activities or incidents. Comparatively, Taylor et al. (1988) suggest that to estimate the success of a programme, one needs to establish the presence of four elements: the presence of written policies; procedures; services; and a training programme. Fleisher and Kaplan's (1988) "six major criteria" (such as reduction of work-related accidents, quality issues, staff and their expertise and finally, programme costs) are a useful mixed bag of programme activities. Chandler's (1989) list, though narrow, presents and covers essential evaluation elements, as discussed by the other groups of authors. Finally, Khorommbi's (2007) suggested list is comprehensive, as it benefited from past experiences and of other authors' works.

Programme evaluation is a tool that helps programme funders, organisations and programme staff to assess whether appropriate services are being offered, set programme goals are met and how to revise the programme in the future. Table 6 lists five types of evaluation that could be utilised for programme evaluation.

TABLE 6

TYPES OF PROGRAMME EVALUATION

\begin{tabular}{|l|l|}
\hline \multicolumn{1}{|c|}{ Evaluation type } & \multicolumn{1}{|c|}{ Factors } \\
\hline $\begin{array}{l}\text { Programme process } \\
\text { evaluation }\end{array}$ & $\begin{array}{l}\text { Here stipulated procedures, steps and stages, are checked to } \\
\text { ascertain whether they are being properly followed as } \\
\text { stipulated. The aim is to ensure that programme } \\
\text { agreements, policies and procedures are adhered to. }\end{array}$ \\
\hline $\begin{array}{l}\text { Programme performance } \\
\text { evaluation }\end{array}$ & $\begin{array}{l}\text { Here aims, goals and procedures as stipulated in } \\
\text { programme policy documents and manuals are assessed. } \\
\text { The aim is to establish whether set goals, over a given time } \\
\text { frame, are being achieved. }\end{array}$ \\
\hline $\begin{array}{l}\text { Programme effectiveness } \\
\text { evaluation }\end{array}$ & $\begin{array}{l}\text { Here programme activities are assessed. The aim is to } \\
\text { establish whether these activities are the best way to } \\
\text { address stipulated needs and ends. }\end{array}$ \\
\hline $\begin{array}{l}\text { Programme efficiency } \\
\text { evaluation }\end{array}$ & $\begin{array}{l}\text { Here the focus is whether the programme is reaching its set } \\
\text { goals, using the best possible ways and means. The major } \\
\text { question is whether whatever is being done gives the best } \\
\text { value for the resources put into it. It is about programme } \\
\text { costs. }\end{array}$ \\
\hline $\begin{array}{l}\text { Programme impact } \\
\text { evaluation }\end{array}$ & $\begin{array}{l}\text { Here the focus of examination is whether programme } \\
\text { activities are changing any activity targeted, and achieving } \\
\text { long lasting positive results. }\end{array}$ \\
\hline
\end{tabular}

\section{PROGRAMME DEVELOPMENT ILLUSTRATION}

The paper ends with an example of conceptualising and setting up an EAP for a higher education institution, in which the author led the initiative, as an illustration of programme development. At the time of writing the programme was not yet operational. Davis (1996) refers to such programmes in higher education institutions as either faculty assistance programmes (FAPs) or campus assistance programmes (CAPs). FAPs or CAPs are employee assistance programmes in an educational institutional work setting and focus on similar programme activities to a regular EAP. The difference is just in the emphasis, as FAPs or 
CAPs are for employees within a particular work setting, educational institutions, where employees may require emphasis on particular issues as a result of the uniqueness of their work environment.

The process of programme development of the said institutional EAP involved necessary steps and activities, including:

- establishment of a small work group for the programme establishment initiative;

- institutional profiling (organisational type, staff profile and size, and jobs profile);

- survey and employee behaviour and actions, in relation to patterns of absenteeism, sick leave, disciplinary and grievance cases;

- needs assessment study of typical problems, needs and organisational challenges;

- consultation with all institutional stakeholders (staff, unions, management);

- benchmarking with other similar education institutions and other organisations;

- the development of policies and structures;

- conceptualisation of programme staff, profile and job duties; and

- presentation of the final report of recommendations to institutional management.

The development of the programme was further guided by the understanding of the nature and uniqueness of higher education environment as a work organisation. Six factors, listed below, were always kept in mind throughout the process included (Davis, 1996).

Profile of staff: A profiling of all 701 institutional staff during 2006 showed that a majority of employees were African (95\%) and male (67\%). One-third of the total were academics (35\%) and the academic division was mostly male (69\%). The largest proportion of women employees in a division was in Administration (41.4\%), and for males, in Services (76.5\%). This staff profile reveals the challenges that the institution still faces to meet goals of Employment Equity Act, as well as its own institutional equity plan. These goals included increasing female representation in both senior administration and in academia.

Profile of students: The institution offers mostly undergraduate degree programmes in commercial, environmental, management, natural and social sciences, and law. The student body consists of about 8500 students, some $55 \%$ of whom were female.

Work environment and structure: The nature of an education institution as a work environment is a challenge. These challenges arise in the form of a concentration of highly skilled and qualified personnel contending with slow job mobility, competition of variety of independent opinions, values and professional work traditions, as well as dynamics of competition for finance and other resources. Another factor is the tradition of the less structured nature of the academic work environment as opposed to the greater structure for non-academic staff. Again, academic staff have to contend with academic stressors of the constantly changing nature of the higher education environment, resource limitations, and professional and publication demands. Non-academic staff, on the other hand, have to contend with administrative and resource challenges found in a traditional work environment.

Competition dynamics: The competitive nature and dynamics of the two constituencies (academic and non-academic staff) are created by these differences of work structure environments.

Staff problems and challenges: An examination of the records at the institutional Human Resource Division revealed that most employee problems, challenges and concerns were in 
relation to seven issues: absenteeism, financial management problems, HIV/AIDS, retirement planning, substance abuse, "staff disputes", legal disputes, "personal advice and counselling needs", non-conducive work environment, and work-related mobility complaints.

Staff disciplinary record: A brief analysis of a six-year period (2000 to 2006) showed that 61 disciplinary cases involving staff members were dealt with to finality by the institutional Disciplinary Committee (DC), translating into an annual average of about 10 staff disciplinary cases. Even though referrals to EAP services should not be seen or used as a tool of punishment, all matters involving staff problems (personal or work related) should be referred to the programme first for recommendation before they are finally settled by an institutional DC. The idea is to assist staff, the institution and management to understand issues and seek amicable solutions to problems in pursuit of a positive and productive work environment. With the setting up of the EAP, the hope is that the need for a DC will be reduced from the current annual rate of 10 cases to fewer cases.

In the end, it was decided that the programme to be established should be a "broad-brush" employee assistance programme. Two aspects of that institutional programme, "programme functions and services" and "programme structure" are presented below.

\section{Programme functions and services}

The first aspect of the programme development example here is the presentation of the six major programmes functions and services. After careful consideration of organisational dynamics (such as operational structures, staff, needs assessment and budget), the programme services and functions of the head of the programme were decided upon, and are presented in Table 7. These are stated in the founding documents of the programme. These are carried out through the programme coordinator, i.e. professional head of the programme.

\section{TABLE 7}

\section{PROGRAMME FUNCTIONS AND SERVICES (PROGRAMME HEAD AND THE} PROGRAMME)

- To serve as liaison office between the Chief Executive and staff, on staff welfare/wellness matters and organisational development issues

- To inform and advise the staff on issues that have impact on their work, wellbeing and careers, as employees of the organisation

- To make assessment of individual personal, social and economic environment, as to how they all impact on the functioning, productivity and personal growth of staff

- To provide professional counselling, assistance, advice and referral to the staff, on identified areas of personal concerns

- To identify and form resource linkages with community and professional service providers on employee problems and needs

- To encourage discussions, focus, improvement and research on identified employee problems, concerns and needs

\section{Programme structure}

The second aspect of programme development example here is the presentation of the structure of the organisational EAP, with its six major programmes factors. These are also stated in the founding documents of the programme. The said institutional EAP policy document states these aspects, which are responsibilities of programme coordinator, i.e. professional head of the programme. These are shown in Table 8. 


\section{TABLE 8}

STRUCTURE: EMPLOYEE ASSISTANCE PROGRAMME

\begin{tabular}{|c|c|c|}
\hline Factor & Programme Structural Issues & Suggestions \\
\hline Type of programme & $\begin{array}{l}\text { Formal title of the } \\
\text { programme } \\
\text { - Type of the programme } \\
\text { - Characteristics of the } \\
\text { programme }\end{array}$ & $\begin{array}{l}\text { Employee Assistance Programme } \\
\text { (EAP) } \\
\text { Limited internal service programme } \\
\text { Broad-brush staff advocacy, counselling } \\
\text { and wellness, with outside referrals }\end{array}$ \\
\hline Programme staff & $\begin{array}{l}\text { Number of programme } \\
\text { staff } \\
\text { Official title of } \\
\text { programme head } \\
\text { Post level }\end{array}$ & $\begin{array}{l}\text { One social work/counselling } \\
\text { professional "EAP Coordinator" } \\
\text { Informed by: qualifications and work } \\
\text { experience (within work level: 9-13) }\end{array}$ \\
\hline $\begin{array}{l}\text { Location and } \\
\text { reporting structure }\end{array}$ & $\begin{array}{l}\text { To whom the programme } \\
\text { reports } \\
\text { The departmental and } \\
\text { physical location }\end{array}$ & $\begin{array}{l}\text { Human Resource (to the Chief Execu- } \\
\text { tive) \& EAP Advisory Committee } \\
\text { Begin within Human Resource \& } \\
\text { Development }\end{array}$ \\
\hline Programme policies & $\begin{array}{l}\text { Presence of programme } \\
\text { policies } \\
\text { Areas that programme } \\
\text { policies cover }\end{array}$ & $\begin{array}{l}\text { To be developed } \\
\text { Staff wellness, advocacy and research }\end{array}$ \\
\hline Services offered & $\begin{array}{l}\text { Type of services the } \\
\text { programme offers } \\
\text { - Leading programme service } \\
\text { focus } \\
\text { - } \begin{array}{l}\text { Payment arrangements for } \\
\text { services rendered }\end{array} \\
\text { - } \begin{array}{l}\text { Employee categories to be } \\
\text { served }\end{array} \\
\text { - Avail service to employees } \\
\text { dependents }\end{array}$ & $\begin{array}{l}\text { Staff wellness and advocacy } \\
\text { Proactive services (advocacy, } \\
\text { preventive and information giving) and } \\
\text { Reactive services (counselling and } \\
\text { resource linkage) } \\
\text { Internal services: no fee; \& External } \\
\text { professional services, individual } \\
\text { resources and medical aid } \\
\text { All full-time employees. Brief assess- } \\
\text { ment and counselling; and referral } \\
\text { recommendations only }\end{array}$ \\
\hline $\begin{array}{l}\text { Resource linkages } \\
\text { and providers }\end{array}$ & $\begin{array}{ll}\text { - } & \text { Internal resource and } \\
\text { service linkages } \\
\text { - } \\
\text { External resource and } \\
\text { service linkages and } \\
\text { providers to be utilised } \\
\text { - External professionals /staff } \\
\text { for referrals for services to } \\
\text { employees } \\
\text { - Types of payment /compen- } \\
\text { sation arrangements for } \\
\text { external service providers }\end{array}$ & $\begin{array}{l}\text { Internal professional service providers } \\
\text { (e.g. university health services, } \\
\text { HIV/AID Unit, Counselling Centre, } \\
\text { Legal Aid Clinic) } \\
\text { Local health and other facilities (e.g., } \\
\text { Health \& Social Development, Justice } \\
\text { and SAPS) } \\
\text { Health \& social service professionals } \\
\text { (social workers, psychologists, nurses, } \\
\text { medical practitioners and the police) } \\
\text { Medical aid scheme. Most services, as } \\
\text { state provided services, may not require } \\
\text { client direct payment }\end{array}$ \\
\hline
\end{tabular}




\section{SUMMARY}

The paper began by defining and explaining the relationship of workplace programmes and social work through the route of occupational social work. General reasons for the establishment of programmes are presented, though each organisation would have its own reasons. These reasons undoubtedly affect the approaches and eventually the activities within each programme. The twelve programme elements as presented in the paper are practical and crucial ingredients that help to ensure a successful implementation of an EAP. They serve to help guide research in the field of workplace programmes. To give practical examples, tabular presentations of how such programmes work are given in the form of EAP functions and services, as well as programme structure.

\section{REFERENCES}

AKABAS, S.H. \& KURZMAN, P.A. 1982. The industrial social work specialist: what's so special? In: AKABAS, S.H. \& KURZMAN, P.A. (eds) Work, workers and work organization: a view from social work. Englewood Cliffs, NJ: Prentice-Hall.

AKABAS, S.H. 1993. Introduction. In: KURZMAN, P.A. \& AKABAS, S.H. (eds) Work and well-being: the occupational social work advantage. Washington, DC: NASW Press.

AKABAS, S.H. 1995. Occupational social work. In: Encyclopedia of Social Work (19th ed). Silver Springs, Maryland, USA: NASW Press.

BALGOPAL, P.R. \& PATCHNER, M.A. 1988. Evaluating employee assistance programmes: obstacles, issues and strategies. Employee Assistance Quarterly, 3(3/4):95105.

BALGOPAL, P.R. 1989. Establishing employee programmes: a cross-cultural perspective. Employee Assistance Quarterly, 5(2):1-20.

BLUM, T.C. \& ROMAN, P.M. 1988. Purveyor organizations and the implementation of employee assistance programmes. The Journal of Applied Behavioral Science, 24(4):397412.

BLUM, T.C. 2004. A description of clients using employee assistance programmes. Gale Group (FindArticles.com. 10 September 2009). Available: $\underline{\operatorname{articles.com} / \mathrm{p} / \mathrm{articles} / \mathrm{mi} \mathrm{m08}}$ 47/is_n2 v16/ai 13510841/.

BREAKING DOWN BARRIERS. 2006. Spectrum. New York: Columbia University School of Social Work.

BUREAU OF NATIONAL AFFAIRS. 1987. Employee assistance programmes: benefits, problems and prospects. Rockville, Maryland, USA: Bureau of National Affairs.

CHABELI, T.N. 2006. Perceptions of employees regarding the utilisation of in-house employee assistance programme model by the North West Department of Education. Pretoria: University of Pretoria. (Unpublished MSD EAP Thesis)

CHANDLER, R.G. 1989. Establishing and evaluating an industrial social work programme: the Seagram, Amhersburg experience. Employee Assistance Quarterly, 3(3/4):33-37.

DANIELS, S. 1997. Employee assistance programmes. Work Study, 46(7):251-253.

DAVIS, A.J. 1996. Employee assistance provision in higher education. Employee Counselling Today, 8(5):4-12. 
DE WINNAAR, E. \& TAUTE, F. 2008. The role of supervisors in the South African Police Service in the successful utilization of the employee assistance programme. Social Work/Maatskaplike Werk, 44(3):263-272.

DU PLESSIS, A. 1988. Employee assistance programmes (EAPs). Social Work Practice, $1: 88$.

DU PLESSIS, A. 1991. A society in transition: EAP in South Africa. EAP Digest, 11(3):3566.

DU PLESSIS, A. 1992. Employee assistance programmes in South Africa: a micro model. Employee Assistance Quarterly, 7(3):29-43.

EMPLOYEEE ASSISTANCE PROFESSIONALS ASSOCIATION SOUTH AFRICA (EAPA-SA). 2005. Standards for employee assistance programmes in South Africa. Johannesburg: EAPA-SA.

ERFURT, J.C. \& FOOTE, A. 1984. Occupational employee assistance programmes for substance abuse and mental health problems. Ann Arbor, Michigan, USA: Institute of Labour and Industrial Relations, University of Michigan.

FLEISHER, D. \& KAPLAN, D.H. 1988. Employee assistance/counselling typologies. In: GOULD, G.M. \& SMITH, M.L. (eds) Social work in the workplace. New York: Springer Publishers.

JOSIAS, B.A. 2005. The relationship between job satisfaction and absenteeism in selected field services section within electricity utility in the Western Cape. Bellville: University of the Western Cape. (Unpublished MComm Thesis)

KHOROMMBI, N.N. 2007. Evaluation of employee assistance programme in the Department of Public Works: Vhembe District. Turfloop: University of Limpopo. (Unpublished MA Thesis)

KURZMAN, P.A. 1987. Industrial social work (occupational social work). In: Encyclopedia of Social Work $\left(18^{\text {th }}\right.$ ed). Silver Springs, Maryland, USA: NASW Press.

KURZMAN, P.A. 1988. The ethical base of social work in the workplace. In: GOULD, G.M. \& SMITH, M.L. (eds) Social work in the workplace. New York: Springer Publishing Co.

KURZMAN, P.A. 1992. Employee assistance programme staffing: past, present and future. Employee Assistance Quarterly, 8(2):79-88.

KURZMAN, P.A. 1993. Employee assistance programmes: towards a comprehensive service model. In: KURZMAN, P.A. \& AKABAS, S.H. (eds) Work and well-being: the occupational social work advantage. Washington, D.C.: NASW Press.

MOGOROSI, L.D. 1997. Employee assistance at the workplace: the South African experiences and model. New York: Columbia University. (Unpublished Doctoral Dissertation)

MYERS, D.W. 1984. Establishing and building employee assistance programmes. Westport, Connecticut, USA: Quorum Books.

PACE, P.R. 2006. Styles of aiding workers evolve for EAPs. NASWNEWS, 51(7). Available: www.socialworkers.org/pubs/news/2006/07/eap.asp. 
PINCUS, A. \& MINAHAM, A.C. 1973. Social work practice model and method. New York: F.E. Peacock Publishers, Inc.

RAMOKOLO, M.E. 2004. The exploration of the resistance of troubled employees to utilise the employee assistance programme at Aventis Pharma. Pretoria: University of Pretoria. (Unpublished MSD EAP Thesis)

ROMAN, P.M. 1990. Alcohol problem: intervention in the workplace. Employee assistance programmes and strategies. New York: Quorum Books.

SMITH, M.L. \& GOULD, G.M. 1993. A profession at the crossroads - present and future. In: KURZMAN, P.A. \& AKABAS, S.H. 1988. Work and well-being: the occupational social work advantage. Washington, D.C.: NASW Press.

SMITH, M.L. 1988. Social work in the world of work. In: GOULD, G.M. \& SMITH, M.L. (eds) Social work in the workplace. New York: Springer Publishers.

SONNENSTUHL, W.J. \& TRICE, H.M. 1990. Strategies for employee assistance programmes: the crucial balance $\left(2^{\text {nd }} \mathrm{ed}\right)$. Ithaca, Cornell University, New York: ILR Press.

SONNENSTUHL, W.J. \& TRICE, H.M. 1992. The job-treatment balance in employee assistance programmes. Alcohol Health \& Research World. Available: www.niaaa. nih.gov/publications/aharw.htm.

SONNENSTUHL, W.J. 1988. Contrasting employee assistance, health promotion and quality of work life programmes and their effects on alcohol abuse and dependence. The Journal of Applied Behavioral Sciences, 24(4):347-364.

STRAUSSNER, S.L.A. 1990. Occupational social work today: an overview. Employee Assistance Quarterly, 5(1):53-55.

TAYLOR, P.A., HOLOSKO, M.J., WAYNE-SMITH, B. \& FEIT, M.D. 1988. Paving the way for EAP evaluation: implications for social work. Employee Assistance Quarterly, 3(3/4):6977.

TRICE, H.M. 1992. Work-related risk factors associated with alcohol abuse. Alcohol Health \& Research World, 6:106-111.

WINKELPLECK, J. \& SMITH, M.L. 1988. Identifying and referring troubled employees to counselling. In: GOULD, G.M. \& SMITH, M.L. (eds) Social work in the workplace. New York: Springer Publishing Company.

ZASTROW, C. 1993. Introduction to social work and social welfare $\left(3^{\text {rd }} \mathrm{ed}\right)$. Wadsworth, California: Brooks-Cole.

Dr Lobelo Mogorosi, Department of Social Work, University of Venda, Thohoyandou, Limpopo Province, South Africa. 